\title{
The Tourist and Recreational Cluster of Rostov Region: Socio-Economic Substantiation and Development Prospects
}

Submitted 11/02/19, $1^{\text {st }}$ revision 14/02/19, $2^{\text {nd }}$ revision 23/05/19, qccepted 07/06/19

\author{
Kazmina L.N. ${ }^{1}$, Makarenko V.S., ${ }^{2}$ Provotorina V.V.., ${ }^{3}$ Grigorenko T.N. ${ }^{4}$
}

\begin{abstract}
:
Purpose: The aims to study the issues of the formation and prospects in Rostov Region of a potential "catalyst" for the development of the socio-economic system of the region - tourist and recreational cluster.

Design/Methodology/Approach: The study applied a cluster approach to the development of territories. Such an approach is the study of the tourist region as an interconnected system of tourist resources, tourist infrastructure, tourist services with an effective system of regional tourism management, the optimal phase of which is a tourist cluster.

Findings: This article includes the study of areas of Rostov Region from the standpoint of the cluster approach, tourist and recreational zoning of Rostov Region, the identification of areas that are promising for the formation of tourist and recreational clusters and socioeconomic substantiation for the functioning of clusters.

Practical Implications: The results of the study can be used in the formation and implementation of regional programs for the development of tourism, economy and social sphere.

Originality/Value: The main contribution of this article is the application of the cluster approach to the investigation of socio-economic development of Rostov Region, as well as zoning the tourist and recreational clusters.
\end{abstract}

Keywords: Cluster, tourist and recreational cluster, regional tourism, zoning, typology of clusters, socio-economic substantiation.

JEL Code: L 83, P 41, Q 51, Q 56.

Paper Type: Research article in a Special Issue dedicated to Russian Economy.

Section 8: Business and Economic Issues.

\footnotetext{
${ }^{1}$ PhD, Associate Professor, the Head of the Department of «Service, Tourism and Hospitality industry», Don State Technical University, kafedra_tiig@mail.ru

${ }^{2}$ PhD, Associate Professor, the Head of the Department of «Service, Tourism and Hospitality industry», Don State Technical University,, Vadim251@yandex.ru ${ }^{3} \mathrm{PhD}$, Associate Professor, the Head of the Department of «Service, Tourism and Hospitality industry», Don State Technical University,, a.lera@mail.ru ${ }^{4} \mathrm{PhD}$, Associate Professor, the Head of the Department of «Tourism», High School of Business, Southern Federal University, grigorenko13@inbox.ru
} 


\section{Introduction}

The issue of the formation and development of regional tourist and recreational clusters is important in scientific research. This issue corresponds with the imperatives of the development of the tourism industry of the state that makes it even more urgent. The tourist and recreational cluster can be one of the "locomotives" of the regional economy. The development of tourist and related industries (hospitality, food, transport, etc.) can cause a multiplier effect and thus contribute to the positive dynamics of the economy of the region as a whole.

One of the expected outcomes in the Conception of the Federal target program "Development of domestic and inbound tourism in the Russian Federation (20192025)" is: "the integrated development of tourist and providing infrastructure of tourist clusters for priority types of tourism". It also reveals the essence of the cluster approach to the development of territories, which involves: "on a limited area concentration of enterprises and organizations engaged into the development, production, promotion and sale of tourism products, as well as activities related to tourism and recreational services" (Rosturizm, 2019).

The modern research base for the study of the cluster development of territories includes the investigations of both Russian scientists and researchers from other countries. In connection with the different aspects of the concept of "cluster", which includes the potential number of system elements of the territory development many case studies are interdisciplinary and use scientific methods of Economics, Geography, Sociology, Demography and other scientific spheres.

The study of the issues related to the problems of this article at the world level is based on the ideas of M. Porter (1990). The issues of the development of the terminological apparatus of the tourist clusters were investigated by Yu.A. Alexandrova (2007), N.V. Khavanova, A.I. Bolshakov (2013), V.I. Kruzhalin, N.V. Shabalina, K.V. Kruzhalin (2014), O.A. Afanas'ev (2016) and others.

It is the formation and further development of tourist clusters as a progressive stage in the evolution of territories of different levels that is able to combine internal and external environment for the development of the tourism industry into a common organic structure. The cluster approach to the development of territories will bring regions to the sustainable development of regional tourism and will help to coordinate the interaction of the tourism industry, tourist infrastructure, large investors for positive dynamics in the development of tourism sector of any region, including Rostov Region.

Within the formation of tourist and recreational clusters on the basis of scientific solutions, as well as using the mechanisms of public-private partnership there will be provided the necessary and sufficient conditions for the rapid development of tourism infrastructure and related services. Nevertheless, at the current stage of the 
research of the scientific problem, its conceptual and terminological apparatus is at the stage of formation, adapting general terminology of the cluster approach to the development of territories. There is no single system of indication of the existence and functioning of tourist and recreational clusters and their system elements, which prevents basic research using a single technique.

The development of tourist and recreational clusters in the regions will not only bring the tourism industry to a new level of the development, but also can have a positive impact on the development of the regional socio-economic sphere and provide additional funds to the state and municipal budgets.

\section{Cluster Approach to the Study of Territories}

The cluster approach to the study of the territory development is based on the general concept of the territorial cluster introduced by M.Porter in 1990. Porter notes that "clusters are an organizational form of consolidation of stakeholders' efforts aimed at achieving competitive advantages in the context of the post-industrial economy" (Porter, 1990). Traditionally used relating to the industrial sphere of the development of territories the cluster approach has expanded the boundaries of its scientific application and covered a number of other geographically organized areas, which include tourism. At the same time, the regional component taking into account the specifics of the tourist resources of the territories began to dominate in the studies.

A kind of "catalyst" for the use of the cluster approach to the tourism sector was the article by Alexandrova, who outlined the basic conceptual apparatus of this approach, the structure of the tourist cluster, its system elements, etc. In the mentioned article, the cluster was understood as a "special form of territorial organization (self-organization) of production in a market economy" (Alexandrova, 2007).

Russian researchers investigated the concept, structure and functioning of tourist clusters in Russia in the 2000-2010s. Thus N.V. Khavanova and A.I. Bolshakov investigated methodological approaches to the design of tourist clusters. The authors in their study determined the main directions of scientific interests in the development of regional tourist clusters and identified three blocks of methods for the formation of a tourist cluster - the pre-project stage, the design stage and activity for the formation and development of the cluster (Khavanova, 2013).

In the study by Kruzhalin, Shabalina and Kruzhalin (2014) there were proposed basic stages of the formation of regional tourist clusters. The uniqueness of this study is that it was conducted taking into account the principles of public-private partnership in the cluster-oriented areas. The main stages of the formation of tourist clusters logically reflect everything: from making the decision on tourist claster 
formation through the development of the project up to the management of regional clusters and training human resorsers to ensure their development. This approach reflects the sequence of formation of tourist and recreational clusters and the specifics of cluster management on principles of public-private partnership. The main feature of the described scheme is its universality, so that it can be adapted to any region.

Afanas'ev (2016) within the framework of this approach identified a number of indicators for ranking and typing clusters on the aggregate quantitative value of the integral indicator and made a similar typing, determined the main types of tourist clusters. In particular, the typification is carried out according to the following classification indicators: the location relating to the centers of generation of tourist flows, the stage of the life cycle, the variety of types of tourist attractions, the spatial and territorial structure of the cluster members, the target groups of consumers, the method of formation, the information availability of the cluster for real and potential consumers.

Regionalization of studies on the problem of the formation and development of tourist clusters and their relationship with the territorial socio-economic systems, was the result of a resource approach to the study of tourist clusters. Any region is a territory with a unique content of tourist resources. Tourist resources include natural, cultural and historical, socio-economic, informational resources.

This study was carried out using a cluster approach to the development of territorial and recreational systems, involving the study of the region in terms of the formation and development of tourist and recreational cluster as a system of effectively interacting tourism industry (including tourism resources - natural, cultural, historical, socio-economic, informational, etc.), tourist infrastructure, service enterprises, representatives of business structures and other potential investors, specially protected natural objects of the region, social and cultural environment, etc.

For the maximum possible objectification of the study, it seems optimal to use a number of methods given below. The method of comparative analysis will allow to compare the districts of Rostov Region in order to objectively assess the development of the territory. The use of the typing method will allow to rank the identified existing and potential tourist and recreational clusters in Rostov Region according to the peculiarities of the development and to identify the main types of clusters. The zoning method will help to identify areas with specific features of the correlation of elements of the territory and limit their spatial areas. The method of indication will allow to isolate the main indicators by means of which the analysis of degree and dynamics of clustering territories is possible. The method of long-term planning will be used to develop recommendations for coordinating the development of elements of tourist and recreational clusters to achieve the sustainable socioeconomic development of the region and to achieve the sustainable development of tourism in Rostov Region. 


\section{Prerequisites of Zoning and Typification of the Forming Tourist and Recreational Clusters of Rostov Region}

Rostov Region has both natural and cultural-historical resources. The territory of the region has a unique geographical position, occupying almost "central" latitude position between the equator and the North pole. Being in the area of temperate climatic zone (at the junction of arid and humid zones) allows to avoid extreme temperature indicators and, as a result, creates an opportunity for the year-round implementation of various types of tourism.

Rostov Region is located in the southern part of the East European plain and partly in the North Caucasusian region, occupying a vast territory in the lower Don River basin. By the type of the surface the area of Rostov Region is a plain, dissected by river valleys and gullies. Rostov Region has a favorable temperate continental climate. The average temperature in January is minus $7^{\circ} \mathrm{C}$, in July is plus $23^{\circ} \mathrm{C}$. The duration of sunshine is 2050-2150 hours per year. In Rostov Region there flows one of the largest rivers in Europe - the river Don ( 2 thousand $\mathrm{km}$ ), there located Tsimlyansk reservoir (its volume is 24 billion cubic meters). The main tributaries of the Don River are Seversky Donets and Manych (official portal of the government of the Rostov Region, 2019). They are navigable. In the South-West of Rostov Region is Taganrog Bay of the Azov Sea.

Cultural and historical resources of the region are determined by its history. The region, being a kind of "buffer" between Central Russia and the North Caucasus, has been influenced by the culture and traditions of various ethnic groups since ancient times. The most important centres and objects of historical and cultural nature that determine the geography of tourist flows, both inbound and intraregional in the territory of Rostov Region are museum-reserves associated with the names of A.P. Chekhov in Taganrog and M.A. Sholokhov in Sholokhovskiy and Bokovskiy districts of the region, as well as Starocherkassk historical and architectural museum-reserve. Not so long ago, in the West of the region there began to form recreational centres: the landscape park "Loga", the country club "Melekhov", the recreation center "Eldorado", offering outdoor recreation with a variety of entertainment for residents and guests of Rostov Region. The southern areas of Rostov Region have the necessary resources for the formation of rural tourism centers.

The development of tourism in some regions, as well as the mutual location of tourist infrastructure and centers of tourists "attraction" makes it possible to talk about the forming local tourist and recreational clusters. It seems rational to use O.A. Afanas'ev's typology for their designation, which is based on the target groups of consumers (Afanas'ev, 2016). 
As a result, on the territory of Rostov Region, the authors identified 4 zones that localize existing and forming tourist and recreational clusters (Table 1). As the basis of zoning and typing there were taken tourist objects in combination with the availability of related infrastructure. It should be noted that some of the selected clusters were formed historically (for example, a tourist cluster "Sholokhov" or historical and ethnographic complex "Tanais"), and some clusters were formed recently or are at the stage of formation (sports and recreation cluster "Rostov-arena" and historical and ethnographic cluster "Park Loga").

Table 1. Zoning of tourist clusters in Rostov Region

\begin{tabular}{|c|c|c|c|}
\hline № & $\begin{array}{l}\text { The cluster } \\
\text { zone title }\end{array}$ & The type and title of the cluster & $\begin{array}{l}\text { Municipal subjects and tourist } \\
\text { centers included into the cluster }\end{array}$ \\
\hline 1 & Northern & $\begin{array}{l}\text { Tourist } \\
\text { "Sholokhovsky»" }\end{array}$ & $\begin{array}{l}\text { Sholokhovskiy, Bokovskiy districts } \\
\text { (The state museum-reserve of M.A. } \\
\text { Sholokhov) }\end{array}$ \\
\hline \multirow[t]{2}{*}{2} & \multirow[t]{2}{*}{ Western } & $\begin{array}{l}\text { Tourist and recreational cluster } \\
\text { "Eldorado" }\end{array}$ & $\begin{array}{l}\text { Kamenskiy district (Base of rest of } \\
\text { "Eldorado" }\end{array}$ \\
\hline & & $\begin{array}{l}\text { Historical and ethnographic } \\
\text { cluster "Park Loga" }\end{array}$ & $\begin{array}{l}\text { Kamenskiy district (the landscape } \\
\text { park "Loga") }\end{array}$ \\
\hline \multirow[t]{6}{*}{3} & \multirow[t]{6}{*}{$\begin{array}{l}\text { South- } \\
\text { Western }\end{array}$} & $\begin{array}{l}\text { The cluster of business tourism } \\
\text { "Business capital» }\end{array}$ & Rostov-on-Don \\
\hline & & $\begin{array}{l}\text { Historical and ethnographic } \\
\text { complex "Cossack" }\end{array}$ & $\begin{array}{l}\text { Novocherkassk, Aksay (village } \\
\text { Starocherkasskaya), Ust-Donetsk } \\
\text { (village Razdorskaya) districts }\end{array}$ \\
\hline & & $\begin{array}{l}\text { Sports and health cluster } \\
\text { "Rostov-arena" }\end{array}$ & $\begin{array}{l}\text { Rostov-on-Don (left bank of the } \\
\text { river Don, stadium "Rostov-arena") }\end{array}$ \\
\hline & & $\begin{array}{l}\text { Tourist cluster "Taganrog - the } \\
\text { birthplace of Chekhov" }\end{array}$ & Taganrog \\
\hline & & $\begin{array}{l}\text { Historical and ethnographic } \\
\text { complex "Tanais" }\end{array}$ & $\begin{array}{l}\text { Myasnikovskiy district } \\
\text { (the historical and archaeological } \\
\text { museum-reserve "Tanais") }\end{array}$ \\
\hline & & $\begin{array}{l}\text { Recreation and health cluster } \\
\text { "Azov Sea and the Don Delta" }\end{array}$ & Azov district, Taganrog, Don Delta \\
\hline \multirow[t]{3}{*}{4} & \multirow[t]{3}{*}{ Eastern } & $\begin{array}{l}\text { Tourist and recreational cluster } \\
\text { "Reserve "Rostovskiy" }\end{array}$ & $\begin{array}{l}\text { Orlovskiy, Remontnenskiy districts } \\
\text { (State natural biosphere } \\
\text { reserve "Rostovskiy") }\end{array}$ \\
\hline & & $\begin{array}{l}\text { Hunting and fishing cluster } \\
\text { "River Don" }\end{array}$ & Tsimlyanskiy, Volgodonsk districts \\
\hline & & wine cluster "Don Valley" & Tsimlyanskiy district \\
\hline
\end{tabular}

These cluster zones have their own features caused by the specifics of natural, cultural and historical development. The Northern zone is the centre of event and cultural and educational tourism associated with the life and work of the writer M.A. Sholokhov. The Western zone has its natural and ethnographic component, as well as places favorable for the rest in the week-end. South-Western zone is the most developed place as a tourist centre. The position of the capital, tourist objects, 
accommodation facilities and a dense transport network are the reasons for the formation of a complex cluster zone that combines different types of tourism.

The developed tourist infrastructure of the centre of the region - Rostov-on-Don in conjunction with the diversified industry and the agricultural sector of the surrounding areas allows to consider the city as a centre of business tourism. The World Cup held in 2018 in Russia became a kind of "catalyst" for the development of inbound tourism in Rostov Region. Infrastructure facilities (accommodation facilities, Platov airport, etc.) were built and improved within preparation to the World Cup. The Eastern zone is oriented on the use of natural tourist resources.

A unique natural area -State natural biosphere reserve "Rostov", combined with the resources of the Tsimlyansk reservoir allows the zone to become a promising area for the development of ecological tourism. In the future, we can talk about the allocation of the Southern zone, which is characterized by a variety of natural resources, in particular, unique steppe landscapes. Currently, there is practically no tourist infrastructure in this area and, as a result, organized tourism, which left the region outside the zoning. The zone can potentially be used for ecological and rural tourism. For optimal functioning and co-development of clusters, it is necessary to form a rational management system. Proposed by the authors perspective management option (figure 1) is headed by the Government of Rostov Region. At the same time, it is necessary to create coordination councils of the tourism cluster both at the level of the region and at the level of its municipalities. The core of the cluster seem to be tourist objects - natural, cultural,historical and socio-cultural.

Figure 1. The perspective structure of the tourist cluster in Rostov Region

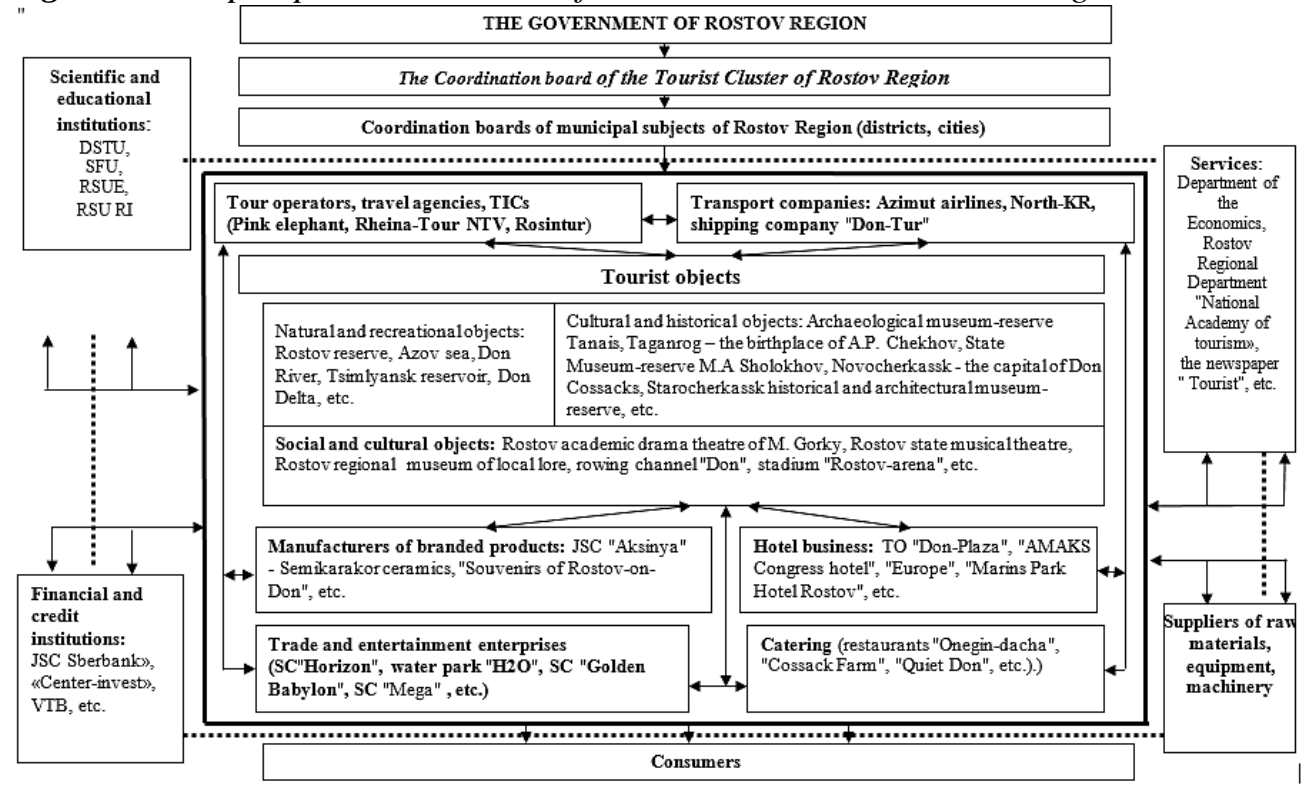


Today in Russia there are realized some perspective tourist investment projects of the formation or modernization of tourist clusters, but, unfortunately, none of them were declared by Rostov Region though it has a high potential of the development of tourist clusters with specialization on priority types of tourism. The functioning of above-mentioned clusters will allow to form a comprehensive tourism product, in particular, to revive the development of the tourist project "Silver horseshoe of Don", which is supposed to include tourist routes in various types of tourism (educational, environmental, ethnographic, rural, water, etc.). At the same time, the co-development and interaction of different cluster zones should lead to the formation of a common tourist and recreational cluster of Rostov Region as the backbone of the socio-economic system of the region. Therefore, the development of the tourism industry of the region, based on the cluster approach is a "point of growth" of the regional economy.

\section{Social and Economic Factors for the Development of Tourist and Recreational Cluster}

The tourism industry is one of the most profitable sectors of the world economy and plays an important, and sometimes the main role in the formation of gross domestic product, strengthening the trade balance, creating additional jobs. The impact of tourism on the economy of the region may be both direct and indirect. Direct impact occurs when tourists spend money in the region. Tourists' money remains in the region and increases its income, i.e. there is a chain of "expenses-income-expenses", and so on.

During the turnover of tourists' expenses in the economy of the region, indirect influence, or "multiplier effect" comes into force. Their money begins to work for the economy of the region at the moment of payment for tourist services. Sellers of services use this money to pay their employees, who spend it for the payment of services, goods, etc. At each stage of the service there are tax deductions to the regional budgets, which subsequently allow representatives of regional authorities to direct received funds to financing the social sphere of the region. To achieve this effect, it is necessary to use one of the forms of economic integration - the formation of tourist clusters.

The tourism sector has a significant synergetic effect, both for related industries and for the socio-economic development of the territory of the tourism cluster localization. And the formation of clusters, due to the general laws of the economy development, now is the development of partnership between the state, economy and science. International experience shows that clustering is the most reliable tool for the development and competitiveness of the industry. At the federal level, the existing cluster initiatives are supported, as the cluster is considered as a tool to improve the competitiveness of the regional economy (Klepikova, 2013). Clustering in Russia is a rather new way of the development and modernization of economic sectors, as a result problems of formation, maturation of clusters and assessment of 
socio-economic effectiveness of their functioning are very actual. Figure 2 shows the complex technique of an assessment of the effectiveness of tourism cluster functioning, based on the works of several authors (Klepikova, 2013; Shutilov, 2013; Avdonina, 2012).

It is reasonable to begin the analysis of the effectiveness of the tourist cluster with an assessment of the contribution of the tourist cluster into the region's economy. The role of formed tourist clusters in the region's economy can be assessed using various indicators shown in Figure 2. The analysis of the target efficiency of the cluster should be based on the calculation of the matching factor (coefficient), taking into account the projected and actual effects of clustering industry.

$$
c=(E f / E p-1) 100 \%,
$$

where $E f$ - the factual effect;

$E p$ - the projected effect.

The zero value of the matching coefficient indicates the most effective coordination of the factual result of the cluster functioning with the projected one, the result of the matching coefficient that is less than zero indicates a shortfall in the projected effect, and the matching coefficient that is more than zero indicates an over-fulfillment of the plan. Integration processes taking place in the tourist cluster, lead to a synergetic effect, which is characterized by the excess of the amount of income from the joint functioning of the cluster members, over the income of the same enterprises from individual functioning.

Thus, it is possible to make a quantitative assessment of the functioning of the participants of the tourism cluster according to the synergetic approach, using the method of comparing the resulting indicators of the activity of the same participants in the cluster and outside it.

\section{Conclusion}

The analysis of research in the field of functioning of tourist and recreational clusters of territories showed that the formation of the cluster can become a "point of growth" for socio-economic development of the region. Through the creation of a multiplier effect, tourist and recreational clusters are able to bring the region to a higher level of the development, to ensure the functioning of infrastructure, to improve the investment climate, to increase tourist flows to Rostov Region.

Spread of tourist resources and the main types of tourism in Rostov Region allows to allocate 4 cluster zones on its territory - Northern, Western, South-Western and Eastern. Each of the zones includes local clusters functioning (now or in future) on the basis of tourist objects. Together, they form the framework of the tourist and recreational cluster of Rostov Region and can become the basis for the further development of the tourism industry of the territory. 
Figure 2. Methods of assessing the effectiveness of the tourist cluster

\begin{tabular}{|c|c|c|}
\hline \multicolumn{3}{|c|}{ Methods of assessing the effectiveness of the tourist } \\
\hline$\downarrow$ & $\downarrow$ & $\downarrow$ \\
\hline $\begin{array}{l}\text { Assessment of the } \\
\text { tourism cluster in the } \\
\text { economy of the region }\end{array}$ & $\begin{array}{c}\text { Expert method of assessment } \\
\text { on a 3-point scale }\end{array}$ & $\begin{array}{l}\text { The quantitative method of } \\
\text { assessment of functioning of } \\
\text { the participants in tourism }\end{array}$ \\
\hline \multirow{2}{*}{$\begin{array}{l}\text { Assessment } \\
\text { clustering } \\
\text { (localization) }\end{array}$} & \multirow{2}{*}{$\begin{array}{l}\text { Availability of competitive } \\
\text { enterprises }\end{array}$} & synergetic approach \\
\hline & & \multirow{4}{*}{$\begin{array}{l}\text { Assessment of the resulting } \\
\text { indicators of the cluster and } \\
\text { indicators of enterprises in a } \\
\text { "cluster-free" position (the } \\
\text { scope of services provided, } \\
\text { Assessment of the company } \\
\text { value, capital productivity, } \\
\text { profitability, etc.). }\end{array}$} \\
\hline \multirow{2}{*}{$\begin{array}{l}\text { Assessment of the } \\
\text { social effectiveness of } \\
\text { the cluster }\end{array}$} & $\begin{array}{l}\text { Implementation } \\
\text { innovative projects }\end{array}$ & \\
\hline & $\begin{array}{l}\text { Growth of economic } \\
\text { indicators of the industry }\end{array}$ & \\
\hline $\begin{array}{l}\text { Assessment of the } \\
\text { target effectiveness of } \\
\text { the cluster }\end{array}$ & $\begin{array}{l}\text { The linkages and } \\
\text { interaction between } \\
\text { members of the clusters }\end{array}$ & \\
\hline $\begin{array}{l}\text { Assessment of the } \\
\text { balance of income and } \\
\text { costs in the tourism } \\
\text { industry }\end{array}$ & $\begin{array}{l}\text { Geographical proximity of } \\
\text { cluster members, the right } \\
\text { choice of cluster members } \\
\text { and their number }\end{array}$ & $\begin{array}{l}\text { Assessment of the possibility } \\
\text { of subsidizing and preferential } \\
\text { investment of the cluster } \\
\text { (state support) }\end{array}$ \\
\hline
\end{tabular}

Clustering of the tourism industry in the region has a number of advantages: increasing the productivity of enterprises, cluster members and as a consequence of this increase in economic effect; expansion of innovation and increase of the number of new enterprises by simplifying access to suppliers and qualified human resources, etc.; increasing productivity; increasing the employment of the region's population in small business forms, forming a tourist cluster; achieving the competitiveness of the region's economy, aimed at a high standard of life of the population, thereby fulfilling the social obligations of the authorities; increasing the investment rating, by attracting additional investments, both into individual elements of the cluster and into the cluster and the region as a whole.

\section{References:}

Afanas'ev, O.E. 2016. Typology of Tourist Clusters Included into the FTP "Development of Domestic and Inbound Tourism in the Russian Federation", 1, 37-45.

Aleksandrova, A.Yu. 2007. Tourist Clusters: Content, Boundaries, Functioning. Modern Problems of Service and Tourism, 1, 51-61.

Avdonina, S.G. 2012. Quantitative Methods for Assessment of the Synergetic Effect of the Innovation Cluster Management of Economic Systems. Electronic scientific journal, 3, available at: http://uecs.ru/uecs-39-392012/item/1147-2012-03-19-08-23-46.

Donland. 2019. Official portal of Government of Rostov Region. Available at: https://www.donland.ru/. 
Khavanova, N.V., Bolshakov, A.I. 2013. Methodological Approaches to the Design of Tourist Clusters. Service Plus, 4, 54-62.

Klepikova, N.I. 2013. Assessment of the Effectiveness of the Industry Cluster Formation. Fundamental Research, 4-4, 934-939, http://www.fundamentalresearch.ru/ru/article/view?id=31301

Kruzhalin, V.I., Shabalina N.V. Kruzhalin, K.V. 2014. Theoretical and Methodological Approaches to Tourist and Recreational Design. Geography, Theory and Practice of Tourism, 139, 100-122.

Porter, M.E. 1990. The Competitive Advantage of Nations. New York, The Free Press.

Regtourism. 2019. About the Region, Tourism. Available at: http://www.donland.ru/?pageid=7725

Shutilov, F.V. 2013. Methods of Assessing the effectiveness and Synergistic Effect of Clusters. Scientific Bulletin of Southern Institute of Management, 2, 81-85. 